\title{
PENINGKATAN MOTIVASI BELAJAR IPA MELALUI IMPLEMENTASI METODE INQUIRY KELAS V SEKOLAH DASAR
}

\author{
Mahlianurrahman' ${ }^{*}$, \\ 1 STAI Darul Hikmah Aceh Barat
}

\begin{abstract}
Abstrak
This research was motivated by the low of motivation learning of class $\mathrm{V}$ students of Pasi Pinang elementary School academic year 2016/2017. This research was held to decribe the effort to improve motivation learning by using inquiry methods and improve learning motivation by using inquiry methods in science. The type of this research was class $\mathrm{V}$ students of Pasi Pinang Elementary School year academic $2016 / 2017$ school year which had 24 students. The object of this research was the improvement of students' motivation using inquiry methods in science subject. The results of this research showed that the use inquiry methods can improve students' motivation learning in learning science subject in class V Pasi Pinang Elementary School academic year 2016/2017.
\end{abstract}

Keywords:
learning motivation,
method inquiry

\section{Pendahuluan}

Pendidikan bertujuan untuk meningkatkan keterampilan siswa melalui pelatihan yang dilakukan dan dilaksanakan secara teratur dan berkesinambungan. Adapun upaya yang harus dilakukan pemerintah untuk meningkatkan mutu sumber daya manusia (SDM) adalah dengan memperbaiki mutu lembaga pendidikan di tingkat dasar. Namun faktanya bahwa pendidikan di Sekolah Dasar (SD) belum sesuai tujuan yang diharapkan terutama pada proses pembelajaran Ilmu Pengetahuan Alam (IPA). Proses pembelajaran merupakan kegiatan yang menyediakan berbagai kesempatan bagi siswa untuk dapat terlibat aktif dalam mengikuti proses pembelajaran, karena melalui proses pembelajaran siswa akan menemukan perubahan perilaku, pengetahuan, sikap, dan keterampilan.

Banyak faktor yang mempengaruhi proses belajar siswa. Salah satu faktor yang mempengaruhi adalah faktor dari dalam atau factor psikologis. I Wayan Widiana (2016), menyatakan bahwa salah satu factor psikologis yang mempengaruhi belajar adalah faktor motivasi. Motivasi merupakan faktor psikologis dalam belajar yang sangat penting. motivasi belajar adalah keinginan atau dorongan untuk belajar. Motivasi dalam hal ini meliputi dua hal yaitu mengetahui apa yang akan dipelajari dan memahami mengapa hal tersebut patut dipelajari". Dengan demikian tanpa adanya motivasi belajar pada diri siswa maka kegiatan belajar akan sulit berhasil. Motivasi sangat dibutuhkan guru untuk menunjang profesionalitasnya sebagai guru sehingga membawa dampak positif bagi pembelajaran. Guru harus mempunyai motivasi untuk menciptakan pembelajaran yang efektif. Terlebih pada guru bahasa Indonesia, pelajaran bahasa Indonesia masih dianggap remeh oleh peserta didik. Akibatnya, siswa kurang berempati dan kurang memperhatikan pembelajaran bahasa Indonesia. Akibatnya, kelas menjadi ramai (dalam arti ramai yang tidak mendukung tercapainya tujuan pembelajaran), siswa tidak memperhatikan penjelasan guru dan siswa tidak berupaya mengerjakan soal dengan baik. Oleh karena itu, guru harus mempunyai motivasi tinggi untuk "menyadarkan" betapa pentingnya pelajaran bahasa Indonesia bagi kehidupan. Hal ini dikarenakan motivasi para guru akan menular kepada siswa yang diajarnya dalam Arista, Made (2015).

Hal tersebut sesuai dengan penjelasan Mahlianurrahman (2017: p. 88) bahwa siswa tidak hanya dituntut untuk paham terhadap materi akan tetapi siswa juga harus mampu menjelaskan makna dari materi sehingga siswa dapat mengarah pada taraf menerapkan materi yang dipahami dalam kehidupan sehari-hari.

* Corresponding author.

E-mail Addresses: Sbsrahman@yahoo.com (Mahlianurrahman) 
Laba Laksana, Dek Ngurah (2016) menjelaskan bahwa Pembelajaran IPA di SD semestinya berpusat pada siswa dan guru harus membiasakan siswanya untuk berkembang secara mandiri melalui penemuan dalam pembelajaran. Guru harus memiliki pengetahuan dan keterampilan dalam mendidik agar pelaksanaan proses pembelajaran dapat berjalan dengan baik sehingga siswa mengikuti pembelajaran dengan penuh semangat dan tujuan pembelajaran dapat tercapai. Penilaian yang diwujudkan di sekolah memiliki tujuan dan karakteristik masing-masing, seperti halnya penilaian dalam mata pelajaran IPA. IPA pada hakekatnya merupakan suatu produk, proses dan aplikasi. Sebagai produk IPA merupakan sekumpulan pengetahuan dan sekumpulan konsep dan bagan konsep. Sebagai suatu proses, IPA merupakan proses yang dipergunakan untuk mempelajari objek studi, menemukan dan membangun produk-produk sains, dan sebagai aplikasi, teori-teori IPA akan melahirkan teknologi yang dapat memberi kemudahan bagi kehidupan.

Mahlianurrahman (2017: p.59) menjelaskan bahwa proses pembelajaran yang baik tidak hanya sekedar menghafal konsep-konsep IPA, akan tetapi proses yang menghubungkan konsep-konsep untuk menghasilkan pemahaman utuh, sehingga konsep yang dipahami tidak mudah dilupakan dan dapat diterapkan dalam kehidupan sehari-hari. Guru menjadi kunci utama dalam meningkatkan pemahaman siswa pada materi IPA serta meningkatkan motivasi belajar siswa dalam memecahkan masalah IPA. dalam proses pembelajaran diperlukan dalam setiap mata pelajaran. Hal ini dapat menjadi salah satu indikator keberhasilan dalam proses pelaksanan kegiatan pembelajaran. Hal ini juga diperlukan dalam kegiatan pembelajaran Ilmu Pengetahuan Alam. Ilmu PengetahuanAlam sebagai sebuah disilplin ilmu dan penerapannya dalam masyarakat membuat pendidikan IPA menjadi penting. Dalam kegiatan pembelajarannya peserta didik diberikan kesempatan untuk berlatih keterampilan-keterampilan IPA, sebab diharapkan mereka dapat berpikir dan memiliki sikap ilmiah. Paolo dan Marten (dalam Carin, 1993) menegaskan di dalam IPA tercakup juga coba-coba dan melakukan kesalahan, gagal, dan mencoba lagi. Ilmu Pengetahuan Alam tidak menyediakan semua jawaban untuk masalah yang diajukan sehingga guru dan siswa harus tetap bersikap skeptis sehingga selalu siap memodifikasi model-model yang kita punyai tentang alam ini sejalan dengan penemuanpenemuan yang kita dapatkan.

Sardiman (2012) menjelaskan bahwa motivasi merupakan serangkaian usaha untuk menyediakan kondisi-kondisi tertentu, sehingga seseorang mau dan ingin melakukan sesuatu, dan bila ia tidak suka, maka akan berusaha untuk meniadakan atau mengelakkan perasaan tidak suka itu (Sardiman, 2012).

Adapun indikator motivasi belajar adalah 1) adanya keinginan dan kebutuhan dalam belajar, 2) ulet dan tekun mengerjakan tugas, 3) adanya kegiatan menarik dalam belajar, 4) memiliki harapan dan cita-cita, dan 5) berusaha mempertahankan pendapat yang diyakini kebenarannya (Hamzah B Uno, 2015; \& Sardiman, 2012).

Berdasarkan hasil wawancara dengan guru SD kelas V Negeri Pasi Pinang dan berdasarkan hasil obeservasi, diperoleh informasi bahwa guru tidak merangsang keaktifan siswa pada saat belajar, sehingga siswa kurang antusias dan pembelajaran terkesan membosankan.

Berdasarkan data hasil ulangan harian siswa diperoleh data bahwa nilai rata-rata siswa hanya 54\%. Berdasarkan hasil observasi pembelajaran bahwa kegiatan belajar mengajar yang dilakukan oleh guru hanya menggunakan metode ceramah, dan tanya jawab.

Hal tersebut tidak sesuai dengan penjelasan Aunurrahman (2010: 143), bahwa penggunaan model pembelajaran yang tepat dapat mendorong tumbuhnya rasa senang siswa terhadap pelajaran, menumbuhkan dan meningkatkan motivasi dalam mengerjakan tugas, memberikan kemudahan bagi siswa untuk memahami pembelajaran sehingga memungkinkan siswa mencapai hasil belajar yang lebih baik.

Masih banyak siswa yang cenderung diam dan kurang fokus mengikuti pembelajaran sehingga konsep yang disampaikan oleh guru tidak dapat dipahami oleh siswa. Mahlianurrahman (2017: p.26) menjelaskan bahwa pemahaman konsep merupakan aspek yang sangat penting, bahkan dalam kegiatan belajar mengajar aspek ini sangat ditonjolkan.

Adapun solusi yang dapat diterapkan dalam mengatasi dan menyelesaikan permasalahanpermasalahan tersebut adalah dengan mengubah metode pembelajaran ceramah yang biasa diterapkan guru dengan metode inquiry. Dari berbagai permasalahan tersebut, maka penelitian ini difokuskan pada motivasi belajar IPA siswa kelas V SD Pasi Pinang melalui penerapan metode inquiry. Penelitian ini secara kusus bertujuan untuk meningkatkan kemampuan motivasi belajar IPA siswa kelas V SD Pasi Pinang.

Menurut Abidin (2014: p.149) bahwa pembelajaran inquiry adalah suatu model pembelajaran yang dikembangkan agar siswa menemukan dan menggunakan berbagai sumber informasi dan ide-ide untuk meningkatkan pemahaman tentang masalah-masalah, topik, atau isu tertentu. Melalui pembelajaran Inquiry, siswa dapat terlibat aktif seperti mengajukan pertanyaan dan penyelidikan sehingga siswa dapat membangun pengetahuan yang bermakna. Penyelidikan adalah suatu sikap, cara dan pedoman yang digunakan siswa untuk menggali, menjelaskan, dan mengenal konsep-konsep IPA. 
Untuk menghindari proses pembelajaran seperti itu maka dilaksanakan model pembelajaran inkuiri, untuk memperbaharui proses belajar siswa. Penggunaan model inkuiri akan menciptakan kegiatan pembelajaran yang lebih menyenangkan dan akhirnya berpengaruh pada pemahaman konsep yang ditemukan. Pada prinsipnya tujuan pengajaran inkuiri membantu siswa bagaimana merumuskan pertanyaan, mencari jawaban atau pemecahan untuk memuaskan keingintahuannya dan untuk membantu teori dan gagasannya tentang dunia. Lebih jauh lagi dikatakan bahwa pembelajaran inkuiri bertujuan untuk mengembangkan tingkat berpikir dan juga keterampilan berpikir kritis. Penerapan model ini sangat penting diterapkan dalam upaya meningkatkan mutu pendidikan. Berdasarkan penelitian yang dilakukan oleh I Ketut Tunas Arnawa (2007).

Banch \& Bell (2008, pp.26-27) menjelaskan bahwa metode inquiry dengan tingkatan rendah adalah penyelidikan terstruktur dan sangat umum digunakan pada di SD. Adapun tahapan pembelajaran dengan menerapkan metode inquiry adalah a) mengobservasi, b) merumuskan pertanyaan yang relevan, c) mengevaluasi buku dan sumber-sumber informasi lain secara kritis, d) merencanakan penyelidikan atau investigasi, e) mereflksi apa yang telah diketahui, f) melaksanakan percobaan atau eksperimen dengan menggunakan alat untuk memperoleh data, g) menganalisis dan menginterprestasi data, dan h) membuat prediksi dan mengomunikasikan hasilnya.

Tahapan-tahapan pembelajaran dengan menerapkan metode inquiry tersebut sesuai dengan pendapat Trianto (2012: p.172), yaitu a) menyajikan pertanyaan atau masalah, b) membuat hipotesis, c) merancang perocobaan, d) melakukan percobaan, e) mengumpulkan dan menganalisis data, dan f) membuat kesimpulan.

Hal tersebut sesuai dengan pendapat Zion \& Mendelovici (2012: p.383) yaitu penyelidikan memiliki tahapan yang dimulai dengan mengidentifikasi permasalahan dengan pertanyaan, pengumpulan data, dan membuat kesimpulan berdasarkan bukti.

Dari beberapa pendapat diatas maka dapat disimpulkan bahwa tahapan pembelajaran dengan menerapkan motode inquiry adalah a) penyajian informasi, b) menyajikan pertanyaan atau masalah, c) membuat hipotesis, d) merancang perocobaan, e) melakukan percobaan, f) mengumpulkan data, g) menganalisis data, dan $\mathrm{h}$ ) membuat kesimpulan.

Pembelajaran metode inquiry memberikan kesempatan kepada siswa untuk mengembangkan kemampuan penyelidikan dengan mendorong siswa untuk mencari dan menemukan pengetahuannya sendiri dengan bimbingan dari guru sesuai dengan proses ilmiah sehingga pembelajaran menjadi bermakna bagi siswa.

Metode inquiry juga mempunyai beberapa kelemahan, yakni sulit mengontrol kegiatan dan keberhasilan siswa, sulit dalam merencanakan pembelajaran karena terbentur dalam kebiasaan awal siswa dalam belajar. Dengan demikian, bisa saja terjadi proses pembelajaran yang panjang sehingga terkendala dengan waktu (Kurniasih \& Sani, 2015).

Wawan Handari ( 2008 ) telah mengadakan penelitian dimana menerapkan Model Pembelajaran Inkuiri dalam pembelajaran IPA untuk meningkatkan hasil belajar IPA pokok bahasan Cahaya pada siswa kelas V SD No. 7 Serang Tahun Ajaran 2008/2009. diketahui bahwa penerapan model pembelajaran inkuiri dapat meningkatkan hasil belajar Matematika. Hal ini ditunjukkan dari hasil penelitian yang dilakukan di kelas III Tianyar, persentase ketuntasan pada siklus I sebesar $54,6 \%$ dan pada siklus II sebesar 73,8\%. Terjadinya peningkatan sebesar 19,2\%. Ni Nyoman Sri Astuti (2010) yang dilakukan di SD Seraya Barat terlihat persentase ketuntasan pada siklus I sebesar $61,90 \%$ dan pada siklus II sebesar 90,48 , terjadi peningkatan sebesar 28,58\%.

Adapun tujuan penelitian ini adalah untuk meningkatkan motivasi belajar IPA melalui penerapan metode inquiry di kelas V SD Pasi Pinang Aceh Barat.

\section{Metode Penelitian}

Jenis penelitian ini adalah penelitian tindakan kelas yang dilaksanakan dalam tiga siklus. Setiap siklus terdiri atas empat tahap, yaitu: perencanaan, pelaksanaan, observasi, dan refleksi. Hasil refleksi akan menjadi bahan evaluasi yang menjadi pertimbangan perbaikan pada siklus berikutnya. Penelitian ini menggunakan desain Kemmis dan Mc Taggart. Berikut ini gambaran desain Kemmis dan Mc Taggart: 


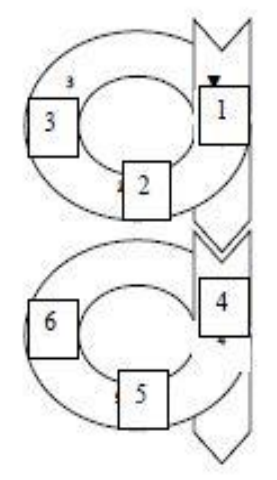

Keterangan:

Gambar 1. Desain Spiral Kemmis dan Mc Taggart

Siklus I:

1. Perencanaan

2. Perlakuan dan pengamatan

3. Refleksi

Siklus II:

4. Perencanaan

5. Perlakuan dan pengamatan

6. Refleksi. (Sumber: Mc Taggart, 1991, p.32).

Tahap rencana merupakan serangkaian tindakan sistematis untuk meningkatkan apa yang hendak terjadi (Sukardi, 2012, p.5). Perencanaan bersifat strategis dan mampu menjawab tantangan yang muncul dalam perubahan, serta dapat mengenal kendala-kendala yang dihadapi. Perencanaan harus fleksibel karena segala rencana yang telah disusun dapat berubah pada keadaan tertentu diluar perencanaan yang tidak dapat diprediksi sebelumnya.

Pada tahap tindakan adalah pelaksanaan dari rencana, dalam hal ini meliputi tindakan yang dilakukan oleh peneliti sebagai upaya untuk meningkatkan motivasi belajar siswa dalam memecahkan masalah IPA serta mengamati hasil atau dampak dari diterapkannya metode pembelajaran inquiry. Selanjutnya observasi dilakukan untuk memperoleh data hasil penerapkan metode inquiry.

Refleksi dilakukan untuk mendiskusikan temuan-temuan yang di dapat saat pelaksanaan kegiatan. Hasil temuan yang telah dikaji kemudian digunakan untuk pertimbangan rencana pada siklus selanjutnya. Setiap akhir siklus dilaksanakan observasi motivasi belajar IPA. Lembar observasi disusun bertujuan untuk mengetahui peningkatan motivasi belajar siswa.

Data hasil observasi dianalisis secara statistik deskriptif dengan menghitung rata-rata, modus, nilai tertinggi, dan nilai terendah kemudian disajikan dalam bentuk tabel dan grafik. Data dalam bentuk persentase dideskripsikan dan diambil kesimpulan tentang masing-masing komponen dan indikator berdasarkan kriteria yang ditentukan. Kriteria Keberhasilan penelitian ini adalah jika siswa yang termotivasi untuk belajar sama dengan atau lebih dari $70 \%$.

Penelitian ini dilaksanakan pada semester genap tahun ajaran 2016/2017. Penelitian ini dilaksanakan di SD Pasi Pinang. Objek dalam penelitian ini adalah siswa kelas V semester genap SD Pasi Pinang yang berjumlah 24 siswa. Adapun instrumen yang digunakan dalam penelitian ini adalah lembar observasi. Tujuan observasi dilakukan untuk memperoleh data yang orisinil dari siswa sebagai informasi yang sangat penting untuk mengetahui motivasi belajar melalui penerapan metode inquiry.

Teknik analisis data dilakukan dengan analisis deskriptif. Setelah semua data terkumpul, maka ditarik kesimpulan dari data yang telah dianalisis untuk mengetahui motivasi belajar siswa. Adapun data dalam penelitian ini dianalisis dengan menggunakan rumus sebagai berikut:

$$
P=\frac{f}{N} \times 100 \%
$$

Keterangan :

P: Angka persentase

f: Frekuensi motivasi belajar siswa 
n: Jumlah motivasi.

Indikator kinerja yang dipakai dalam penelitian tindakan kelas ini adalah terjadi peningkatan motivasi belajar siswa dengan menggunakan metode pembelajaran inkuiri.

\section{Hasil Dan Pembahasan}

Adapun hasil analisis deskriptif motivasi belajar pada siklus I, siklus II, dan siklus III adalah:

Tabel 1. Hasil Analisis Motivasi belajar

\begin{tabular}{lccc}
\hline \multicolumn{1}{c}{ Motivasi Belajar } & Siklus & Siklus & Siklus \\
& I & II & III \\
\hline Jumlah Siswa & 24 & 24 & 24 \\
Rata-Rata & 60.2 & 74.6 & 92.8 \\
\hline
\end{tabular}

Lebih jelasnya rata-rata kemampuan motivasi belajar siswa adalah:

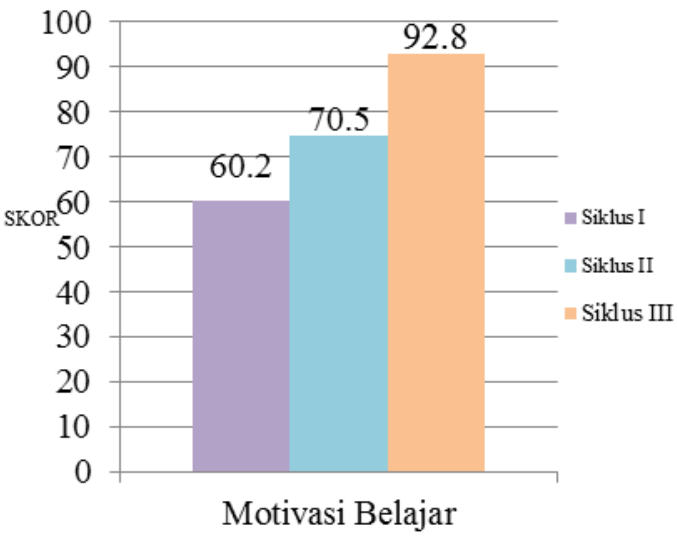

\section{Gambar 1. Histogram Skor Rata-rata Hasil Belajar}

Berdasarkan gambar 1 diketahui bahwa rata-rata siswa yang termotivasi pada siklus I adalah $60.2 \%$, siklus II $70.5 \%$, dan siklus III 92.8\%. hal tersebut menunjukkan bahwa motivasi belajar siswa setiap siklusnya mengalami peningkatan. Berdasarkan hasil analisis menunjukkan bahwa penerapan metode inquiry pada kelas V SD Pasi Pinang meningkat.

Penelitian ini menerapkan metode inquiry pada materi bumi dan alam semesta di kelas V Pasi Pinang. Fokus dalam penelitian ini adalah melihat peningkatan motivasi belajar siswa dengan menerapkan metode inquiry. Berdasarkan hasil observasi bahwa adanya beberapa masalah yang ditemukan saat proses pembelajaran IPA di kelas V SD Negeri Pasi Pinang. Masalah yang ditemukan di antaranya yaitu guru tidak merangsang keaktifan siswa pada saat belajar, sehingga siswa kurang antusias dan pembelajaran terkesan membosankan. Berdasarkan data hasil ulangan harian siswa diperoleh data bahwa nilai rata-rata siswa hanya 54\%. Kegiatan belajar mengajar yang dilakukan oleh guru hanya menggunakan metode ceramah, dan tanya jawab. Masih banyak siswa yang cenderung diam dan kurang fokus mengikuti pembelajaran sehingga konsep yang disampaikan oleh guru tidak dapat dipahami oleh siswa.

Adapun solusi yang dapat diterapkan dalam mengatasi dan menyelesaikan permasalahanpermasalahan tersebut adalah dengan mengubah metode pembelajaran ceramah yang biasa diterapkan guru dengan metode inquiry. Masalah-masalah yang telah diuraikan merupakan faktor yang menyebabkan motivasi belajar pada pelajaran IPA siswa kelas V SD Negeri Pasi Pinang rendah.

Mengamati kondisi yang demikian, tampaknya diperlukan adanya suatu tindakan guna perbaikan pembelajaran untuk meningkatkan hasil belajar IPA di SD kelas V SD Negeri Pasi Pinang dengan menerapkan salah satu metode pembelajaran yaitu metede pembelajaran inquiry.

Pratiwi (2017) menjelaskan bahwa metode pembelajaran inquiry memiliki keunggulan, yaitu pembelajaran yang menekankan kepada pengembangan aspek kognitif, afektif, dan psikomotor secara 
seimbang, dapat memberikan ruang kepada siswa untuk belajar sesuai dengan gaya belajar mereka, sesuai dengan perkembangan psikologi modern yang menganggap belajar adalah proses perubahan, dapat melayani kebutuhan siswa yang memiliki kemampuan diatas rata-rata.

Langkah pertama yang dilakukan guru adalah dengan mengajukan suatu permasalahan guna memancing pengetahuan yang dimiliki siswa. Guru membimbing siswa dalam mengidentifikasi beberapa masalah sesuai permasalahan yang telah diajukan guru. Guru dapat membantu siswa dengan membagi siswa dalam beberapa kelompok secara heterogen sehingga siswa dapat duduk bersama anggota kelompoknya untuk mendiskusikan dan mengidentifikasi suatu masalah.

Dalam pelaksanaan metode pembelajaran inquiry terbimbing, guru menyediakan bimbingan atau petunjuk cukup luas kepada siswa. Guru memberikan pengarahan dan bimbingan kepada siswa dalam melakukan kegiatan-kegiatan, sehingga siswa yang berpikir lambat atau siswa yang mempunyai kemampuan berpikir rendah tetap mampu mengikuti kegiatan-kegiatan yang sedang dilaksanakan dan mempunyai intelegensi tinggi. Pembelajaran menggunakan metode pembelajaran inquiry terbimbing, guru tidak melepas siswa begitu saja, melainkan memberikan bimbingan agar alur pembelajaran sesuai dengan tujuan yang telah ditetapkan. Bimbingan yang diberikan guru lebih banyak berupa pernyataan dan pertanyaan pengarah. Selain dikemukakan langsung oleh guru, pernyataan dan pertanyaan pengarah juga diberikan melalui Lembar Kerja Siswa (LKS) agar siswa mampu menemukan sendiri arah dan tindakan-tindakan yang harus dilakukan untuk memecahkan permasalahan.

Langkah kedua merupakan tahap membuat hipotesis. Hipotesis merupakan dugaan sementara sehingga guru membimbing siswa dalam memberikan kesempatan siswa dalam membuat hipotesis yang sesuai dengan permasalahan yang telah diperoleh dan menentukan suatu hipotesis yang menjadi prioritas dalam melakukan penelitian yang akan dilakukan. Dalam tahap membuat hipotesis, siswa menyampaikan pendapat mengenai hipotesis yang relevan dengan masalah yang telah diperoleh.

Langkah ketiga yaitu tahap pengumpulan data. Pada tahap ini, guru membimbing siswa dalam memperoleh informasi melalui percobaan yang dilakukan oleh siswa. Siswa melakukan diskusi bersama anggota kelompok untuk memperoleh data atau informasi yang relevan dan dapat menyelesaikan masalah yang telah diperoleh.

Kegiatan selanjutnya adalah siswa mengumpulkan laporan untuk diperiksa guru. Mendiskusikan masalah-masalah yang ditemukan selama percobaan, memeriksa dan menyimpan kembali segala bahan dan peralatan yang digunakan. Siswa dengan bimbingan guru melaksanakan percobaan berdasarkan panduan dalam LKS yang telah dibagikan. Pelaporan hasil percobaan dan beberapa perwakilan kelompok diminta mempresentasikan hasil eksperimennya serta kelompok lain memberikan tanggapan. Siswa diberikan kesempatan oleh guru untuk menanyakan hal-hal yang belum dimengerti. Siswa dengan bimbingan guru menyimpulkan materi pelajaran.

Langkah terakhir yaitu membuat simpulan, di mana siswa dibimbing oleh guru dalam membuat simpulan dari hasil percobaan yang telah dilakukan oleh masing-masing kelompok. Langkah-langkah pembelajaran tersebut telah dilakukan sesuai dengan pendapatnya Hidayah (2017). yaitu (a) orientasi masalah, (b) konseptualisasi, (c) investigasi, (d) menarik kesimpulan, dan (e) mendiskusikan.

Berdasarkan perolehan data hasil tindakan penelitian pada siklus I dapat dinyatakan bahwa ratarata siswa yang termotivasi untuk belajar belum mencapai indikator yang sudah ditentukan. Oleh karena itu, masih diperlukan upaya perbaikan guna mencapai indikator pada siklus II.

Pelaksanaan siklus II yang dilakukan menunjukkan adanya peningkatan perolehan nilai rata-rata pada mata pelajaran IPA yaitu $70.5 \%$. Berdasarkan perolehan nilai rata-rata tersebut, menunjukkan bahwa tindakan siklus II telah memenuhi indikator keberhasilan yang ditetapkan. Peneliti mencoba melanjutkan penelitian hingga siklus III guna untuk melihat kekonsistenan peningkatkan motivasi belajar siswa.

Pelaksanaan siklus III yang dilakukan menunjukkan adanya peningkatan perolehan rata-rata siswa yang termotivasi untuk belajar dengan menerapkan metode inquiry pada mata pelajaran IPA yaitu 92.8\%. Berdasarkan perolehan rata-rata tersebut, menunjukkan bahwa tindakan siklus III meningkat lebih besar dibandingkan siklus II.

Selama tindakan perbaikan proses pembelajaran, digunakan metode pembelajaran inquiry yang mampu meningkatkan motivasi belajar IPA. Hal ini didasarkan pada kelebihan inquiry yang dapat membantu siswa aktif dalam mencari permasalahan yang dihadapi, mengembangkan kemampuan berpikir dan bekerja secara ilmiah yang menekankan pengalaman belajar secara langsung.

Sebagaimana Artana (2015) menjelaskan bahwa metode pembelajaran inquiry terbimbing memberi kesempatan kepada siswa untuk mengembangkan ide-idenya secara sendiri yang melibatkan semua indranya. Fakta-fakta penelitian di atas, memberikan dukungan mengenai penggunaan metode Inquiry yang dapat meningkatkan motivasi belajar IPA. 
Sejumlah kelebihan metode inquiry yang ditemukan dari penelitian yang telah dilakukan, antara lain dapat meningkatkan motivasi belajar siswa dalam memecahkan masalah IPA, terbiasa menuangkan pemikiran dalam bentuk lisan maupun tulisan, siswa dapat menghasilkan solusi dalam memecahkan masalah, siswa dapat memehami konsep-konsep IPA, dan siswa mendapatkan pengalaman langsung melalui proses pembelajaran.

Hal tersebut sesuai dengan hasil penelitian Ayurachmawati, P. (2017), bahwa kemampuan yang muncul setelah penerapan pembelejaran IPA dengan menerapakan metode inquiry adalah kemampuan mengajukan pertanyaan, kemampuan merencanakan penyelidikan, kemampuan menggunakan perlengkapan sederhana dan alat untuk mengumpulkan data serta kelengkapan menuliskan langkah percobaan, kemampuan menggunakan data untuk mengkonstruksi penjelasan yang memiliki perbedaan komposisi penjelasan hasil penelitian, dan kemampuan mengkomunikasikan hasil penelitian.

Dari pembahasan tersebut, maka dapat disimpulkan bahwa penerapan metode inquiry dapat meningkatkan motivasi belajar IPA siswa kelas V Pasi Pinang

\section{Simpulan dan Saran}

Hasil penelitian menunjukkan bahwa pelaksanaan pembelajaran dengan menerapkan metode inquiry dapat meningkatkan motivasi belajar IPA kelas V SD Pasi Pinang, hal tersebut terlihat pada siklus pertama hingga siklus ke tiga.

Berdasarkan hasil penelitian ini, maka peneliti memberikan saran-saran sebagai berikut: 1) Mengingat proses belajar mengajar dengan menerapkan metode inquiry memberikan peningkatan motivasi belajar IPA, maka diharapkan kepada guru untuk dapat menerapkan metode inquiry pada meteri bumi dan alam semesta secara berkesinambungan, 2) Kepala sekolah hendaknya memberi bimbingan dan mengarahkan guru untuk dapat menerapkan metode inquiry dalam proses pembelajaran yang sesuai dengan materi IPA sehingga motivasi belajar siswa dapat meningkat.

\section{Daftar Pustaka}

Abidin, Yunus. (2014). Desain Sistem Pembelajaran dalam Konteks Kurikulum 2013. Bandung : PT. Refika Aditama.

Arista, Made. 2015. Analisis Motivasi Belajar Dalam Pembelajaran IPA Siswa Kelas IV PadaTiga SD di Gugus VI Kecamatan Buleleng Tahun Pelajaran 2014/2015. Skripsi. Singaraja: Universitas Pendidikan Ganesha

Aunurrahman. (2010). Belajar dan Pembelajaran. Bandung: CV. Alfabeta.

Artana, I. M. A., Dantes, N., \& Lasmawan, I. W. (2015). Pengaruh Model Pembelajaran Inkuiri Terbimbing terhadap Hasil Belajar IPA Ditinjau dari Minat Belajar Siswa Kelas V SD Negeri di Gugus VI Kecamatan Abang Kabupaten Karangasem Tahun Pelajaran 2014/2015. Jurnal Pendidikan Dasar, 5(1).

Ayurachmawati, P., \& Widodo, A. (2017). Analisis Kemampuan Inkuiri Siswa Di Sekolah Dasar. Eduhumaniora: Jurnal Pendidikan Dasar, 8(2), 217-227.

Banch, H. \& Bell, R. (2008) The many levels of inquiry. Journal NSTA Science and Children. 26-30.

Carin, Antur A. 1993. Teacing modern science. Sixth edition. New York: merril. Publishers.

Hidayah, N., Suryandari, K. C., \& Ngatman, N. (2017). Penerapan Model Inquiry Terbimbing dalam Peningkatan Motivasi Belajar IPA tentang Energi dan Perubahannya pada Siswa kelas V SD Negeri Klegenwonosari. Kalam Cendekia PGSD Kebumen, 5(5.1).

Kurniasih, Imas dan Berlin Sani. (2015). Ragam Pengembangan Model Pembelajaran. Jakarta: Kata Pena.

Laba Laksana, Dek Ngurah. 2016. Miskonsepsi Dalam Materi IPA Sekolah Dasar. Jurnal Pendidikan Indonesia Vol 6.No 2 tahun 2016. (http://ejournal.undiksha.ac.id/ index.php/JPI/article/view/8588).

Mahlianurrahman, M. (2017). Pengaruh Pendekatan Science, Environment, Technology And Society (SETS) Terhadap Pemahaman Konsep, Berpikir Kreatif Dan Peduli Lingkungan Siswa Kelas IV SD Ngablak. Bina Gogik: Jurnal Ilmiah Pendidikan Guru Sekolah Dasar, 4(1).

Mahlianurrahman, M. (2017). Pengembangan Perangkat Pembelajaran SETS Untuk Meningkatkan Pemahaman Konsep dan Sikap Peduli Lingkungan Siswa Sekolah Dasar. Premiere Educandum: Jurnal Pendidikan Dasar dan Pembelajaran, 7(01), 58-68.

Mahlianurrahman, M. (2017). Pengembangan Perangkat Pembelajaran untuk Meningkatkan Kemampuan Berpikir Kreatif Siswa Sekolah Dasar. AR-RIAYAH: Jurnal Pendidikan Dasar, 1(01), 87-106.

McTaggart,R. (1991). Action Research: a Short Modern History. Victoria: Deakin University Press. 
Putu Ayu Pryantini, Made Sumantri, I Wayan Widiana. (2016). Pengembangan Asesmen Proyek Dalam Pembelajaran Ipa Di Kelas V Semester I Sd Negeri 1 Sangsit Kecamatan Sawan Kabupaten Buleleng Tahun Pelajaran 2015/2016. Vol: 4 No: 1 Tahun: 2016. e-Journal PGSD: Universitas Pendidikan Ganesha Jurusan PGSD.

Pratiwi, N. L. K. A. Y., Ganing, N. N., Hum, M., \& Wiarta, I. W. (2017). Pengaruh Model Pembelajaran Inkuiri Terhadap Kompetensi Pengetahuan IPA Siswa Kelas IV SD Gugus Letkol Wisnu Tahun Ajaran 2016/2017. Mimbar PGSD, 5(2).

Sardiman. (2012). Interaksi \& Motivasi Belajar Mengajar. Jakarta : PT Raja Grafindo Persada.

Sadirman, A.M. (2007). Interaksi dan Motivasi Belajar Mengajar. Jakarta: PT Raja Grafindo Persada.

Sukardi.(2012). Metode Penelitian Pendidikan Tindakan kelas implementasi dan pengembangannya. Jakarta: Bumi Aksara.

Trianto. (2012). Mendesain Model Pembelajaran Inovatif-Progresif Konsep, Landasan, dan Implementasinya dalam Kurikulum Tingkat Satuan Pendidikan (KTSP). Jakarta: Kencana Prenada Media Group.

Uno, H.B. (2015). Teori Motivasi \& Pengukurannya. Analisis Di Bidang Pendidikan. Jakarta: PT Bumi Aksara

Widiana, I Wayan. 2016. Pengembangan Asesmen Proyek Dalam Pembelajaran IPA di Sekolah Dasar. Jurnal Pendidikan Indonesia Vol 6.No 2 tahun 2016. (http://ejournal.undiksha.ac.id/ index.php/JPI/article/view/8154).

Zion, M. \& Mendelovici, R. (2012). Moving from structured to open inquiry: challenges and limits. Journal Science Education International. Voume l, Number 4, 4 Desember 2012, 383-399. 